\title{
Associations Between Family Factors and Premarital Heterosexual Relationships Among Female College Students in Tehran
}

By Farideh Khalaj Abadi Farahani, John Cleland and Amir Hooshang Mehryar

Farideh Khalaj Abadi Farahani is assistant professor, Population Studies and Research Centre in Asia and the

Pacific, Tehran, Iran.

John Cleland is professor, Department of Epidemiology and Population Health,

Centre for Population Studies, London

School of Hygiene and Tropical Medicine.

Amir Hooshang

Mehryar is professor,

Department of Behavioral Sciences, Institute for Research on Management and Planning, Tehran, Iran.

\begin{abstract}
CONTEXT: Although premarital heterosexual relationships, especially those involving sexual contact, are discouraged in Iran, particularly for females, a considerable minority of young people are involved in such relationships. However, the determinants of such relationships have not been identified, especially those pertaining to family.
\end{abstract}

METHODS: In 2005-2006, a random sample of 1,378 unmarried female college students from four universities in Tehran completed anonymous, self-administered surveys that asked whether the respondent had ever had a premarital heterosexual relationship. Bivariate and multivariate regression analyses were conducted to examine associations between such relationships and family factors, including socioeconomic measures, parent-child communication and closeness, family values and atmosphere, and parental control.

RESULTS: Having had a boyfriend was positively associated with paternal income (odds ratio, 1.3), maternal educational attainment (1.3) and more liberal family values (1.3), and negatively associated with parent-child closeness (0.6). Very strict and very relaxed parental control during adolescence were both associated with having had a boyfriend, but only the former was associated with having had premarital sex. In addition, respondents were more likely to have had premarital intercourse if they did not live with both parents (2.0) or if their family had more liberal values (1.3); they had reduced odds of having had sex if they had a closer relationship with their parents (0.7).

CONCLUSION: Good family relationships may reduce the likelihood that youth will engage in premarital sex, possibly by fostering parent-child closeness. Moderate parental control may discourage premarital relationships more effectively than lesser or greater degrees of control.

International Perspectives on Sexual and Reproductive Health, 2011,37(1):30-39, doi: 10.1363/3703011

The age at which women and men marry has increased substantially in Iran during the past few decades. Among women, for example, the mean age at marriage increased from 19.7 in 1976 to 23.3 in $2006 .{ }^{1}$ The proportion of women aged 20-24 who had never married was $21 \%$ in 1976, compared with about 50\% in 2006 (80\% in urban areas). ${ }^{1,2}$ As a result of this change, the gap between puberty and marriage has increased considerably. Any relationships (particularly sexual ones) between men and women outside of marriage are socially, culturally, legally and religiously forbidden in Iran, and most Iranians consider it important that young people (especially females) abstain from any physical intimacy and sex until marriage. * However, recent evidence suggests that the prevalence of premarital relationships is rising among young people. If these relationships do not lead to marriage, the psychological, emotional and social consequences tend to be greater for females than for males, because of the double standards regarding male and female sexuality and the importance of virginity for

*In this article, the term "physical intimacy"encompasses kissing, hugging and touching, but not intercourse, and "physical relationship" refers to a physically intimate relationship. "Sex" refers to any type of penetrative sex. In addition, we refer to any premarital heterosexual relationship, whether sexual or not, as a "friendship" or "relationship," and we refer to the males in such relationships as "boyfriends." If the relationship involves sex, we refer to it as an "intimate" or "sexual" relationship. young women's marriage prospects.

The development of attitudes regarding heterosexual relationships and sexuality, and the learning of appropriate norms, both begin early in life, and these processes are influenced by the family environment and by the values and behaviors of parents and other family members. The family provides role models, a social and economic environment and standards of sexual conduct. ${ }^{3}$ However, the specific dimensions of family life that influence the formation of sexual behavioral patterns among young people in Iran are not well understood.

Because societal norms should be similar for most females in a particular society, variation among individuals in premarital heterosexual relationships and intimacy presumably is attributable primarily to individual and familial characteristics. Because many individual-level factors, such as attitudes and self-efficacy, are also influenced by an individual's behavior, the direction of causality is not always clear. However, factors related to family structure and function are less likely influenced by individual sexual behavior, and hence they can be considered determinants or predictors of sexual behaviors in cross-sectional studies. In this article, we aim to identify familial factors that are associated with premarital friendships and sex among a representative sample of female college students. 


\section{BACKGROUND}

Although regional and ethnic variations in marriage patterns and family formation are evident in Iran, ${ }^{4}$ Islamic values play a significant role in homogenizing Iranian society and are considered an important factor in marriage and family formation. Islam emphasizes the sanctity of the family and the importance of forming a family. In contrast, it condemns remaining unmarried after maturation, as well as divorce, although neither is forbidden. ${ }^{5}$ Traditionally, Iranian men and women have been under social pressure to marry early. Nonetheless, strict religious rules have proscribed heterosexual relationships and associations outside of marriage, limiting open interactions between unmarried men and women. Interactions between prospective partners traditionally have been possible only under family supervision, particularly for females, ${ }^{6}$ and marital choices have been made primarily by parents and family members. ${ }^{7}$

Although these cultural and religious values are still in place, in recent decades changes have occurred in Iranian families' attitudes and behaviors, which in turn have led to changes in family formation and the marriage system. ${ }^{8}$ These changes include longer intergenerational gaps and more equal gender norms. Even though Iranian society has roots in Islamic values, it has made strides toward modernity. Because striking a balance between tradition and modernity is one of the main concerns of Iranian families, the norms surrounding marriage and family are becoming increasingly heterogenous. ${ }^{8}$

Among the social interactions that have been affected considerably by the recent changes in Iranian society are premarital friendships and intimacy between members of the opposite sex. Although heterosexual relationships before marriage, particularly intimate ones, are generally condemned, recent evidence suggests that an increase in such relationships has occurred. Access to global media and communications technology, as well as immigration, has increased Iranians' exposure to permissive values. Satellite programming, though illegal, is widely accessible; in 2002, 27\% of male adolescents in Tehran, Iran's capital, reported having access to satellite programs, and 34\% had access to the Internet. ${ }^{9}$ The corresponding figures among female college students in Tehran in 2005-2006 were 56\% and $86 \%$, respectively. ${ }^{10}$ In addition, owing to increases in Iranian women's educational aspirations ${ }^{11}$ and in economic barriers to marriage, age at first marriage has risen considerably in recent decades; ${ }^{2}$ hence, the gap between puberty and marriage has widened, a situation that some young people and families may consider as a justification for premarital heterosexual relationships.

In some instances, premarital relationships may be sanctioned through temporary marriage, a form of marriage practiced in pre-Islamic Arabia that has been legally permitted and religiously sanctioned among Twelver Shiites, most of whom live in Iran. ${ }^{12,13}$ Historically, temporary marriage, or sigheh, has been practiced in special cases where there is an urgent sexual need but no possi- bility of permanent marriage. The marriage contract must specify the bride price and the duration of marriage (which can be as short as a few minutes or as long as 99 years) and can be renewed. In addition, the relationship needs to be registered by a cleric in a marriage registry, particularly if it results in the birth of a child.

Despite its religious imprimatur, sigheh has never been very popular in Iran, particularly among unmarried youth, and the majority Sunni sect has banned the practice. The lack of popularity may be attributable in part to tradition that dictates that women be (or can claim to be) virgins when they marry; many Iranians assume that a woman who enters a temporary marriage is not a virgin. An ethnographic study in Iran showed that women who contract temporary marriages are primarily young divorced women (generally from a lower-class background). ${ }^{12}$ A revised family law has recently been endorsed in the Iranian parliament; under this law, if enacted, temporary marriages that meet certain criteria will need to be registered to place them in a more legal framework. ${ }^{14}$

As the costs of permanent marriage are high, unemployed youth might defer such marriages because they cannot afford it. ${ }^{15}$ Clerics and officials have begun to discuss sigheh as a possible solution to this problem. However, the public response to this proposal has not been favorable. Opponents argue that temporary marriage promotes promiscuity, complicates the issue of legal paternity and has negative effects on the stability of permanent marriage. ${ }^{15}$ Advocates respond that some young men and women already have sexual relationships, and that these relationships will not result in promiscuity if they are defined within an Islamic framework of temporary marriage. Advocates further note that women cannot be involved in another relationship for a certain period of time after termination of the temporary marriage, that any children resulting from the marriage are considered legitimate $e^{16}$ and that couples in temporary marriages can easily use birth control to avoid having a child. Temporary marriage would have important implications for sexuality, birth control, STIs, morality, religion and gender relations, but clerics and leading thinkers have not begun to analyze these implications in a comprehensive way. ${ }^{12}$

Because of sensitivity issues, very few detailed studies on premarital sexuality have been conducted in Iran, and most are unpublished. According to studies published in 2003 and 2005 , some $54-58 \%$ of male and female college students had been involved in premarital heterosexual friendships, ${ }^{17}$ and $8-12 \%$ of female college students had had premarital sex. ${ }^{17,18}$ In other studies, $13-28 \%$ of adolescent males in Tehran reported having had premarital sexual contact; however, because the type of sexual experience was not elicited, the prevalence of sexual intercourse could not be determined. ${ }^{9,19}$ Moreover, little is known about the factors that influence young people's sexual behavior in Iran.

In the international literature, a wide range of predictors of sexual behavior among young people has been identified. Among adolescents, living with a single parent is associated 
with having had sex ${ }^{20}$ and with early onset of intercourse. Findings regarding the relationship between family income and the onset of sex have been mixed. However, studies have consistently shown that parent-child closeness and connectedness are associated with sexual abstinence, postponement of sexual intercourse and having fewer sexual partners. ${ }^{21-23}$ Studies of the relationship between parental control and premarital sex have yielded contradictory results. Some have suggested that parental supervision and monitoring reduces adolescents' risk of pregnancy; ${ }^{20}$ in addition, family values and household routines, ${ }^{24,25}$ parental supervision of dating activities ${ }^{26}$ and parental monitoring in general ${ }^{27-29}$ have been linked with teenagers not having intercourse and, if they do, with their having a later sexual debut and fewer sexual partners. However, perhaps because parental control is multidimensional, other studies have found that excessive or coercive parental control is associated with behavioral and other problems among teenagers, ${ }^{30,31}$ and intrusive maternal control has been linked to early age at first sex. ${ }^{32}$ International studies have also found that the combination of parents' sexual values and parent-child communication may influence adolescent sexual experience. ${ }^{21,27,33,34}$ Mediating mechanisms have also been examined; for instance, several studies have suggested that a lack of parent-child closeness increases the negative impact of peers on adolescents' sexual activity. ${ }^{35-38}$

\section{Theoretical Issues}

Because of the complex array of factors associated with sexual behavior, a single theory might not fully explain premarital sexual relationships in Iran. Hence, to guide our analysis, we used a conceptual framework based on the literature and subsequently refined it according to the study findings. Sexual activity is fundamentally social, in that it explicitly or implicitly involves two or more persons, ${ }^{39}$ and sexual norms are initially learned through interactions with parents and family members during childhood and adolescence. Family structure and parents' socioeconomic characteristics are assumed to influence elements of the family environment related to adolescent sexual behaviors and are placed at the top of the framework. Subjective norms-an expression of the individual's perceptions of external pressures (from parents and others) to comply or not comply with a norm-are also important. Perceived parental control and family values are two factors that may affect an adolescent's compliance with parental attitudes or norms regarding sexual behavior and thus are also included in the framework. Finally, family atmosphere, parent-child communication and parent-child closeness may all be directly or indirectly associated with an individual's premarital behavior.

Using this framework, we examine the following questions: In what ways do the socioeconomic characteristics, structure and values of a young woman's family predict her having had premarital relationships and sex? What elements of family function, such as parent-child communication and parental control, predict these outcomes?
Although a young woman's attitudes might mediate the relationship between her parents' normative beliefs and her own behavior, they are excluded from our conceptual framework and from our analysis because of their reciprocal relationship with sexual behavior.

\section{METHODS}

\section{Sample}

This analysis uses survey data from a mixed method study conducted in 2005-2006 among female college students at four multidisciplinary universities (private and public) in Tehran. To calculate the necessary sample size, we hypothesized that $14 \%$ of students at private universities and $8 \%$ of those at government universities are sexually experienced. In order to detect this difference with a 95\% confidence interval and $80 \%$ power, taking into account the ratio of female students at private versus public universities (1.5) and the design effect needed because of cluster sampling (2), we estimated that a sample size of about 2,000 was needed.

We used two-stage stratified cluster sampling. After determining the proportions of students studying each discipline at these universities, we estimated the required sample for two strata (discipline and type of university) using probability proportionate to size. Next, we calculated the proportion of respondents needed from specific disciplines at private and public universities. Three public universities were randomly selected out of the 19 such institutions in Tehran in 2005; the city had only one private university, so the sample of private university students was obtained from that school. Next, clusters (classes) were selected at random at each university with equal probability without replacement, until the required sample size for the university was reached. On average, each class comprised 23 female students. All females in each class were invited to participate. The main reason for limiting the study to females was that the principal investigator is female; because of the sensitivity of the subject, time restrictions, and the necessity for the investigator to closely supervise and control all aspects of data collection, it was more feasible to limit the study to female students than to include both sexes. Certainly, in Iran, conducting a similar survey among young men would have required a male facilitator.

Data were collected during formal classes from October 2005 to May 2006. Students were assured of confidentiality, and those who did not wish to participate left the classroom. Students provided written consent before completing the anonymous questionnaires. The response rate was about $90 \%$. A total of 1,748 students from 75 classes completed the survey; five questionnaires were missing answers to key questions and were discarded, leaving a sample size of 1,743 . We further restricted our analyses to the 1,378 students who were unmarried ( $80 \%$ of the sample). However, because of missing data, in some analyses the sample size is slightly smaller. Approval for the study was provided by the ethics committee of Shahid Beheshti University, university authorities and disciplinary directors. 


\section{Survey Instrument}

The structured, self-administered questionnaire consisted of 183 questions on topics such as personal characteristics, motivations and goals, family, leisure activities, socialization, interaction with peers, reproductive health knowledge, norms regarding premarital heterosexual relationships, sexual intentions and experiences, personal and peers' beliefs regarding sexuality and gender, and selfefficacy. It also included a social desirability scale to examine whether respondents were being truthful.

- Outcomes. The first outcome variable was whether the respondent had ever had a boyfriend. A boyfriend was defined as someone with whom the respondent had had an emotional, physical or sexual relationship and had spent time alone, irrespective of marital motivations. The other outcome variable was having had sexual intercourse, defined as vaginal sex, anal sex or both.

- Explanatory measures. We asked a series of questions to assess aspects of the family environment, such as values, atmosphere and communication. Response options for each question were on a five-point Likert scale. Because these aspects of family life are conceptually complex, we created scales for each. To construct each scale, we identified survey questions that seemed relevant to the concept; the respondent's scores for these items were totaled (after reverse coding, if needed) to obtain a scale score. To reassess the underlying structure of the family factors, we conducted a confirmatory factor analysis (principal component analysis) with iteration and varimax rotation. Loading patterns suggested that it was appropriate to separate items according to our conceptual framework. Five factors, which explain about $63 \%$ of variation in the family measures, were loaded.

The first factor was mother-daughter communication on sensitive issues. The six-item scale included questions about the degree to which the respondent and her mother talked about sexual matters, and the extent to which the mother informed the respondent about puberty, menstruation, the reproductive system, contraception and sex. Possible total scores for this scale ranged from six (poor communication) to 30 (good communication).

The second factor, family values, consisted of five questions concerning parents' religiosity, modernity, and attitudes toward premarital heterosexual friendship, premarital mixed-sex parties and dating. Possible total scores ranged from five (very conservative) to 25 (very liberal).

The next factor, family atmosphere, encompassed questions regarding five aspects of family life: open communication, kindness, conflict, happiness and time spent together. Possible scores again ranged from five (negative atmosphere) to 25 (positive atmosphere).

The fourth factor was parent-child closeness or attachment. The two-item scale consisted of questions about the respondent's respect for her parents' views about relationships and sex, and the consistency between her and her parents' sexual values. Possible scores ranged from two (little closeness and attachment) to 10 (high closeness and
TABLE 1. Selected characteristics of unmarried female college students, Tehran, 2005-2006

\begin{tabular}{|c|c|}
\hline Characteristic & $\begin{array}{l}\% \text { or mean } \\
(\mathrm{N}=1,378)\end{array}$ \\
\hline \multicolumn{2}{|l|}{ Social and demographic } \\
\hline Age (mean) & 21.4 \\
\hline Not religious & 18.0 \\
\hline Ever smoked & 9.4 \\
\hline Ever drank alcohol & 9.8 \\
\hline Access to satellite television & 56.3 \\
\hline Access to Internet & 86.1 \\
\hline \multicolumn{2}{|l|}{ Academic } \\
\hline \multicolumn{2}{|l|}{ School type } \\
\hline Private & 69.0 \\
\hline Government & 31.0 \\
\hline \multicolumn{2}{|l|}{ Area of study } \\
\hline Medical & 11.3 \\
\hline Human science & 55.5 \\
\hline Basic science & 13.3 \\
\hline Technical/engineering & 9.7 \\
\hline Arts & 10.1 \\
\hline Attends single-sex university & 13.7 \\
\hline \multicolumn{2}{|l|}{ Family } \\
\hline \multicolumn{2}{|l|}{ Father's monthly income } \\
\hline Low (<poverty line) & 19.3 \\
\hline Medium & 41.4 \\
\hline High & 39.3 \\
\hline Resides in Tehran & 86.9 \\
\hline Respondent lives with both parents & 88.7 \\
\hline Mother's education (mean) $\dagger$ & $3.8(1.11)$ \\
\hline Father's education (mean) $\dagger$ & $4.1(1.03)$ \\
\hline Family atmosphere (mean)‡ & $18.6(3.59)$ \\
\hline Family values (mean)‡ & $11.9(3.98)$ \\
\hline Parental control during adolescence (mean)† & $3.3(0.83)$ \\
\hline Mother-daughter communication (mean)§ & $16.1(6.35)$ \\
\hline Parent-child closeness/attachment (mean)t† & $7.1(2.31)$ \\
\hline
\end{tabular}

tOn a scale of $1-5$. $\neq$ On a scale of $5-25$. $§ O n$ a scale of $6-30$. + †On a scale of 2-10. Notes: All values are percentages unless otherwise indicated and are weighted.Values in parentheses are standard deviations.

attachment).

The fifth factor, parental control, consisted of a single item concerning how permissive or strict the respondent's parents had been when she was an adolescent. Scores ranged from 1 (very permissive) to 5 (very strict).

Finally, we included five socioeconomic and demographic variables. Father's monthly income was classified as low (less than the 2005 poverty level of 3 million rials, or about US\$300), medium (3-5 million rials) or high (more than 5 million rials). Family residence was dichotomized as being in Tehran or elsewhere. Mother's education and father's education were each categorized on a scale ranging from one (illiterate) to five (university educated). Lastly, we asked whether the respondent lived with both parents.

\section{Validity and Reliability of Measures}

To maximize the validity of the survey questions, a qualitative study that included in-depth interviews and focus group discussions was conducted prior to survey administration. The findings were used to determine the appropriate language for the study population.

Because of time constraints, we did not undertake formal tests of reliability using the test-retest method. However, to improve the reliability of the questionnaire, we 
TABLE 2. Selected characteristics of unmarried female college students, according to whether they had ever had a boyfriend or ever had sex, Tehran, 2005-2006

\begin{tabular}{|c|c|c|c|c|}
\hline \multirow[t]{2}{*}{ Characteristic } & \multicolumn{2}{|c|}{ Ever had boyfriend } & \multicolumn{2}{|c|}{ Ever had sex } \\
\hline & $\begin{array}{l}\text { No } \\
(\mathrm{N}=653)\end{array}$ & $\begin{array}{l}\text { Yes } \\
(\mathrm{N}=695)\end{array}$ & $\begin{array}{l}\text { No } \\
(\mathrm{N}=1,184)\end{array}$ & $\begin{array}{l}\text { Yes } \\
(\mathrm{N}=133)\end{array}$ \\
\hline \multicolumn{5}{|l|}{ Percentages } \\
\hline Father's income < poverty line & 21.9 & $16.9^{* * *}$ & 20.0 & $14.9^{*}$ \\
\hline Family resides in Tehran & 83.7 & $89.7^{* *}$ & 86.7 & 89.4 \\
\hline Respondent lives with both parents & 89.5 & $87.5^{*}$ & 88.7 & $82.9^{*}$ \\
\hline \multicolumn{5}{|l|}{ Means } \\
\hline Mother's education $†$ & 3.6 & $4.0^{* * *}$ & 3.8 & $4.1^{* *}$ \\
\hline Father's educationt & 4.0 & $4.2^{* * *}$ & 4.1 & $4.3^{*}$ \\
\hline Family atmosphereł & 19.1 & $18.1^{* * *}$ & 18.7 & $17.2^{* * *}$ \\
\hline Family valuesł & 10.3 & $13.4^{* * *}$ & 11.7 & $15.1^{* * *}$ \\
\hline Parental control during adolescence $†$ & 3.3 & $3.4^{* *}$ & 3.3 & $3.5^{*}$ \\
\hline Mother-daughter communication§ & 16.6 & $15.8^{*}$ & 16.3 & $14.9^{*}$ \\
\hline Parent-child closeness/attachment $† \dagger$ & 8.1 & $6.1^{* * *}$ & 7.3 & $5.5^{* * *}$ \\
\hline
\end{tabular}

${ }^{*} p<.05 .{ }^{* *} p<.01 .{ }^{* * *} p<.001$. †On a scale of $1-5 . \neq$ On a scale of $5-25$. §On a scale of $6-30 .+$ tOn a scale of $2-10$. Notes: All values are weighted. The sample sizes for the two outcome variables differ because of missing data.

used carefully worded multiple-item indicators, and the principal investigator was present during survey administration to answer queries.

To minimize social desirability bias, respondents were assured of anonymity and confidentiality. In addition, the Eysenck Lie Scale was used to control for the tendency to give socially desirable answers. This scale, which was assessed in Iran in 1995, ${ }^{40}$ includes nine questions with yes or no responses, ${ }^{*}$ yielding a scale score ranging from 0 to 9. A higher score indicates a greater probability that the respondent is giving untruthful answers. We used this scale to examine whether respondents who reported less socially acceptable behaviors (having had a boyfriend or premarital sex) were more truthful than those who did not report these behaviors. Mean scores did not differ between those who reported having had a boyfriend or having had sex and those who did not report these behaviors or did not answer the question, which strongly suggests that the results are reliable and trustworthy.

TABLE 3. Odds ratios (and 95\% confidence intervals) from logistic regression analyses identifying associations between unmarried female college students' characteristics and their having had a boyfriend

\begin{tabular}{lll} 
Characteristic & Unadjusted & Adjusted \\
\hline $\begin{array}{l}\text { Father's income } \\
\text { Family residence }\end{array}$ & $1.32(1.14-1.53)^{* * *}$ & $1.28(1.02-1.60)^{*}$ \\
$\quad \begin{array}{l}\text { Tehran (ref) } \\
\text { Other }\end{array}$ & 1.00 & 1.00 \\
Lives with both parents & $0.59(0.42-0.82)^{* *}$ & $0.72(0.47-1.11)$ \\
Yes (ref) & 1.00 & 1.00 \\
No & $1.22(0.87-1.70)$ & $1.65(0.97-2.80)$ \\
Mother's education & $1.31(1.19-1.45)^{* * *}$ & $1.27(1.05-1.53)^{*}$ \\
Father's education & $1.21(1.09-1.34)^{* * *}$ & $0.82(0.66-1.00)$ \\
Family atmosphere & $0.92(0.89-0.95)^{* * *}$ & $0.99(0.94-1.04)$ \\
Family values & $1.26(1.22-1.31)^{* * *}$ & $1.25(1.20-1.31)^{* * *}$ \\
Parental control during adolescence & $1.19(1.05-1.36)^{* *}$ & $1.30(1.08-1.58)^{* *}$ \\
Mother-daughter communication & $0.98(0.96-0.99)^{*}$ & $0.99(0.97-1.02)$ \\
Parent-child closeness/attachment & $0.63(0.60-0.67)^{* * *}$ & $0.63(0.58-0.68)^{* * *}$ \\
Nagelkerke $R^{2}$ & & 0.44
\end{tabular}

${ }^{*} \mathrm{p}<.05 .{ }^{* *} \mathrm{p}<.01 .{ }^{* * *} \mathrm{p}<.001$.Notes: Models control for age. All variables are continuous except for father's income, which is categorical, and family residence and whether respondent lives with both parents, which are dichotomous. Odds ratios for continuous and categorical variables reflect changes in odds per one-unit change in measure.
Finally, the reliability of family-level scales was assessed by examining the consistency among scale items (itemitem correlation) using the Cronbach's alpha coefficient. The coefficients for all scales were well above 0.8.

After entry and cleaning, the data were analyzed using SPSS-16. Associations between family factors and the primary outcomes were examined using bivariate and multivariate analysis. All data were weighted to represent the proportions of students in each discipline at the four universities.

\section{RESULTS}

The mean age of the 1,378 unmarried respondents was 21 (Table 1, page 33). About one in 10 had ever smoked or had alcohol, and more than half had access to satellite television (56\%) or the Internet (86\%). Fifty-two percent had ever had a boyfriend, while $23 \%$ had had some type of sexual contact and $10 \%$ had had intercourse (not shown).

In bivariate analyses, women who had ever had a boyfriend or had ever had intercourse were less likely than other women to report that their father's income was below the poverty line and that they lived with both parents (Table 2). In addition, their parents were more highly educated than the parents of other respondents. Family residency in Tehran was associated with having had premarital relationships, but not with having had premarital sex.

Scores on all five family scales differed according to respondents' premarital activity. Family atmosphere was poorer among women who reported having had a boyfriend or having had sex than among their counterparts without such experiences (mean scores, 18.1 vs. 19.1, and 17.2 vs. 18.7, respectively). In addition, family values were significantly more liberal among students who had had premarital relationships or sex compared with those who had not (13.4 vs. 10.3, and 15.1 vs. 11.7, respectively). Contrary to our expectations, parental control during adolescence was stricter among those who reported premarital friendships or sex than among other women (3.4 vs. 3.3, and 3.5 vs. 3.3, respectively). Levels of mother-daughter communication on sensitive issues were lower among students who reported experiencing premarital friendships or sex than among others (15.8 vs. 16.6 , and 14.9 vs. 16.3 , respectively). Finally, parent-child closeness was a strong predictor of premarital heterosexual activity, as mean scores were lower among respondents who had had a boyfriend or premarital sex than among those who had not (6.1 vs. 8.1 , and 5.5 vs. 7.3 , respectively).

To sum up, having had a boyfriend or having had sex was more common among young women whose parents were well-off, were well educated, had liberal family values and had relaxed attitudes toward premarital relationships, and among young women who reported a poor family at-

*The scale asks whether the respondent has committed a variety of acts that are nearly universal but generally condemned, such as breaking promises, becoming jealous or angry, and acting selfishly; the idea is that respondents who do not admit to such behaviors are probably lying. 
mosphere, low levels of mother-daughter communication, lack of parent-child closeness and strict parental control.

\section{Correlations Among Family Factors}

Many family factors were significantly intercorrelated (not shown), but most coefficients were moderate (i.e., less than 0.50 ) or weak. Not surprisingly, mother's and father's education were strongly correlated (coefficient, 0.71 ), and both were moderately linked to father's income $(0.37-0.40)$. Family atmosphere was moderately associated with mother-daughter communication (0.36) and parent-child closeness (0.44), but only weakly with family values (0.09). Liberal family values were positively correlated with parental education (0.29-0.31), father's income (0.23) and motherdaughter communication $(0.20)$, and negatively correlated with parent-child closeness $(-0.11)$ and parental control $(-0.20)$. Parental control, in turn, was negatively and weakly correlated with both parent-child closeness and motherdaughter communication ( -0.13 and -0.10 , respectively).

\section{Logistic Regression Analyses}

In unadjusted logistic regression models, most family factors were associated (positively or negatively) with having had a boyfriend; the only exception was living with both parents (Table 3). In multivariate logistic models that included all of the family measures and controlled for age, some of the explanatory variables-family residence, father's education, family atmosphere and mother-daughter communication-were no longer associated with young women's having had a premarital relationship. However, several remained associated with such relationships, including higher paternal income (odds ratio, 1.3), higher maternal education (1.3), greater levels of parental control during adolescence (1.3), more liberal family values (1.3) and lower levels of parent-child closeness (0.6).

The predictors of premarital sex were generally similar (Table 4). The crude odds ratios were significant for all of the family factors apart from family residence, living with both parents and father's education. In the adjusted model, premarital sex was no longer associated with father's income, maternal education, family atmosphere or motherdaughter communication. However, not living with both parents became a significant predictor of premarital sex in the multivariate model (odds ratio, 2.0). Other characteristics associated with premarital sex were more liberal family values (1.3), greater parental control (1.6) and lower parentchild closeness (0.7).

\section{DISCUSSION}

Despite cultural, legal and religious prohibitions against premarital intimacy (particularly sex), about half of unmarried young women attending college in Tehran reported having had a boyfriend. Moreover, nearly a fourth reported that they had had some type of sexual contact, although only one in 10 said that they had had sexual intercourse. These findings are fairly consistent with those of recent small-scale studies that had less representative samples of Iranian col-

TABLE 4. Odds ratios (and 95\% confidence intervals) from logistic regression analyses identifying associations between unmarried female college students' characteristics and their having had premarital sex

Characteristic

Father's income

Family residence

Tehran (ref)

Other

Lives with both parents

Yes (ref)

No

Mother's education

Father's education

Family atmosphere

Family values

Parental control during adolescence

Mother-daughter communication

Parent-child closeness/attachment

Nagelkerke $R^{2}$

${ }^{*} \mathrm{p}<.05 .{ }^{* *} \mathrm{p}<.01 .{ }^{* * * *} \mathrm{p}<.001$.Notes: Models control for age.All variables are continuous except for father's income, which is categorical, and family residence and whether respondent lives with both parents, which are dichotomous. Odds ratios for continuous and categorical variables reflect changes in odds per one-unit change in measure.

lege students. $17,41,42$ Females are far less likely than males to report having had sexual intercourse, in part because of the importance placed on female virginity in Iran. Although many of the educated females in our sample had had a boyfriend, only a small fraction of these relationships had resulted in penetrative sex. However, the mean age of our sample was 21 , and $81 \%$ of respondents were younger than 23 ; it is likely that with increasing age the proportion of heterosexual friendships resulting in intercourse would be higher. Moreover, many of these relationships might lead to risky sexual behavior, because detailed information on sexual health and prevention of STIs and HIV are not formally provided to unmarried youth in Iran.

We found that father's income and maternal education are predictors of premarital heterosexual friendship, but not of sexual intercourse. This suggests that families with higher incomes and education levels may hold more liberal views regarding premarital associations with the opposite sex, but not regarding sex itself. In-depth interviews with our study participants (data not reported) suggest that some female college students who remain virgins do so to improve their opportunities for marriage. Although they might have greater experience of premarital heterosexual friendships than other women do, they may abstain from sex until marriage. These females might be better informed than their peers of the negative consequences of sex for their marriage prospects because of their higher levels of communication and closer relationships with their parents. In addition, young women who have wealthier, bettereducated parents might be more likely than other women to have liberal peers and easy access to the Internet and satellite television-factors linked with having liberal attitudes and a greater likelihood of having had premarital friendships. However, results from diverse cultural contexts regarding the association between family income and education and onset of sex are contradictory; some relate high- 
er parental education and income to postponement of premarital sexual intercourse, ${ }^{20,43}$ while others have not found such a relationship. ${ }^{44}$

Not living with both parents may be associated with distorted family relationships and family dysfunction and was a predictor of premarital intercourse in our multivariate analysis. Intercourse before marriage is considered a deviant behavior in Iranian culture and is associated with poor communication and a less positive family atmosphere. Studies have consistently shown that adolescents who live with a single parent are more likely than their peers to have had sexual intercourse $e^{20,45,46}$ and to have initiated sex at an earlier age, ${ }^{45}$ and that single or divorced parents hold more permissive sexual attitudes ${ }^{46}$ and supervise their children to a lesser degree than other parents. ${ }^{47}$

We found that family values (which reflected family endorsement of religion and tradition, and parental views regarding premarital heterosexual associations) were linked with both premarital friendship and intercourse. In particular, the more liberal the family values, the greater the likelihood that a young woman had had a boyfriend or premarital sex. Our correlation matrix showed that liberal values were negatively correlated with parental control, suggesting that liberal parents have less control over their adolescents than other parents do. Moreover, parents tend to transmit their values and attitudes to their children; hence, we might expect that liberal parents are more likely than other parents to have daughters who hold liberal attitudes and are willing to associate with men before marriage.

Motivation to comply with family values or parents' sexual beliefs is believed to be an important influence on teenagers' sexual behavior. Positive motives to comply with parental expectations may include consistency of parent-child views and morals and children's respect for their parents' views, which together were conceptualized in this study as parent-child closeness or attachment. Another motive, which can be considered negative, may be concern that parents might discover the premarital relationship. In preliminary logistic models not presented here, we found that parent-child closeness mediates the associations of family atmosphere and mother-daughter communication on sensitive issues with young people's sexual behaviors. This finding suggests that parent-child closeness can act as a pathway through which a positive family atmosphere and satisfying parent-child communication may influence youths' sexual behavior. In other words, better family atmosphere and parent-child communication may lead to more consistent parent-child sexual values and greater respect for parents' sexual attitudes (our measures of better parent-child closeness), and thus lead to lower levels of premarital heterosexual friendship and sexual intercourse. Studies of family processes and relationships have consistently shown that parent-child closeness is associated with lower adolescent pregnancy risk, primarily through delaying and reducing adolescent sexual activity. ${ }^{48}$

The findings further suggest a U-shaped relationship between parental control and premarital friendship. A chisquare test found that both low and high levels of parental control were associated with premarital friendships. In addition, the correlation matrix showed that low parental control was associated with more permissive parental attitudes, which in turn were associated with greater odds of premarital friendship in the multivariate analysis; the multivariate analysis also found that strict control is a predictor of premarital friendship. Thus, we can expect both extremes of parental control (very relaxed or very strict) to be associated with elevated odds of premarital heterosexual relationships. One interpretation is that strict parental control might reflect lack of parent-child trust, which might encourage greater premarital association with the opposite sex, while very relaxed parental control might be related to having more liberal parents, which also is associated with elevated odds of having had a boyfriend. Thus, one might suggest that modest parental control is the best approach for minimizing the likelihood of premarital heterosexual friendships among youth in Iran. However, because parental control in this study was reported by the young women, and not by their parents, our results should be interpreted with caution.

Our findings do not support a U-shaped relationship between parental control and premarital intercourse, as only strict parental control was a predictor of this outcome. This finding challenges the common belief that parental strictness inhibits premarital sex. Strict parental control was negatively correlated with parent-child communication and closeness, and this lack of communication and closeness between parents and child may affect female sexual behavior. In this study, respondents were asked only one question about parental control during adolescence; using multiple questions about parental monitoring and control to build a scale would have allowed a more precise evaluation. However, several studies have found results similar to ours. ${ }^{48-50}$ Some concluded that a low level of parental monitoring is a predictor of early sex. ${ }^{51}$ These findings might not be comparable to ours, however, because of differences in the measurement of parental control and because parental monitoring is poorly defined in most studies. Further research is needed to examine the role of parental control in premarital relationships and sex in Iran, ideally using responses from both parents and children.

A limitation of our study is its cross-sectional design, which does not permit us to determine causality. Most of the factors related to the family are unlikely to have been influenced by respondent behavior, as many of the predictors preceded the sexual behaviors. However, the possibility exists that young women's sexual behaviors may have influenced their perceptions of family-related variables, particularly since only the young women, and not their parents, were asked about these factors. ${ }^{51}$ For example, respondents' interpretations of parental control may have been influenced by their own sexual behaviors.

Several aspects of this study strongly suggest that the re- 
sults are reliable and trustworthy: Levels of missing values were low, particularly for sensitive questions; the coefficients of the reliability tests for scales were high; and mean scores on the Eysenck Lie Scale did not differ between young women who reported sensitive behaviors and those who did not. Nevertheless, because of cultural sensitivity regarding female sexuality in Iran, the prevalence of heterosexual relationships and sex might have been underreported.

Finally, a comparison of predictors of premarital friendship and intercourse reveals similarities and differences. Father's income and parental education (especially mother's) were predictors of having had a boyfriend but not of having had sex. On the other hand, strict parental control, lack of parent-child closeness and liberal family values were associated with both premarital friendship and sex. Interestingly, not living with both parents was a predictor of premarital sex, but not friendship. Therefore, premarital heterosexual friendship is more related to positive family factors and modernity, while premarital sex appears to be more closely linked with poor family outcomes and relations. These results suggest the need for comprehensive studies that use qualitative and quantitative methods to examine the role of family structure and processes on the sexual behavior of young people in Iran. Such studies might be able to provide some policy guidance.

\section{REFERENCES}

1. Abbasi-Shavazi MJ, McDonald P and Hosseini-Chavoshi M, The Fertility Transition in Iran: Revolution and Reproduction, New York: Springer, 2009

2. Abbasi-Shavazi MJ, Recent changes and the future of fertility in Iran, paper presented at the Expert Group Meeting on Completing the Fertility Transition, New York, Mar. 11-14, 2002.

3. Fox GL, The family's role in adolescent sexual behavior, in: Ooms T, ed., Teenage Pregnancy in a Family Context: Implications for Policy, Philadelphia, PA, USA: Temple University Press, 1981, pp. 71-130.

4. Abbasi-Shavazi MJ and Sadeghi R, Ethnicity and patterns of marriage in Iran, Women's Studies, 2005, 3(1):25-47 (in Persian).

5. Ghaemi A, The Constitution of Family Life in Islam, Tehran, Iran: Tehran Parent-Child Association, 1984 (in Persian)

6. Tashakkori A and Thompson VD, Cultural change and attitude change: an assessment of postrevolutionary marriage and family attitudes in Iran, Population Research and Policy Review, 1988, 7(1):3-27.

7. Abbasi-Shavazi MJ, McDonald P and Hosseini-Chavoshi M, The family and social change in post-revolutionary Iran, in: Yount KM and Rashad H, eds., Family in the Middle East: Ideational Changes in Egypt, Iran and Tunisia, New York: Routledge, 2008, pp. 217-235.

8. Mohseni M and Pourreza A, Marriage and Family in Iran, Tehran, Iran: Arvan, 2003 (in Persian).

9. Mohammadi MR et al., Reproductive knowledge, attitudes and behavior among adolescent males in Tehran, Iran, International Family Planning Perspectives, 2006, 32(1):35-44.

10. Farahani FKA, Norms, attitudes and sexual conduct among female college students in Tehran: implications for reproductive health policy and research, unpublished dissertation, London: London School of Hygiene and Tropical Medicine, 2008.

11. Statistical Centre of Iran, Population and housing census, 2004 $<$ http://www.sci.org.ir>, accessed May 2005.

12. Haeri S, Temporary marriage: an Islamic discourse on female sexuality in Iran, in: Afkhami M and Friedl E, eds., The Eye of the Storm:
Women in Post-Revolutionary Iran, London: I.B. Tauris, 1994, pp 98-114.

13. Mirkhani E, Recognizing borders in temporary marriage, Journal of Women's Social and Cultural Council, 2001, 9:7-26 (in Persian).

14. Alia F, The political appearance of Family Law, Oct. 23, 2010 $<$ http://www.tebyan.net/index.aspx?pid=140637>, accessed Oct. 25, 2010 (in Persian)

15. Shepard BL and DeJong JL, Breaking the Silence and Saving Lives: Young People's Sexual and Reproductive Health in the Arab States and Iran, Boston, MA, USA: Harvard School of Public Health, 2005.

16. Karamporian A and Amini B, Sexual deviation in the family and its consequences, paper presented at the Second Congress on Family and Sexual Disorders, Tehran, Iran, Nov. 23-24, 2005 (in Persian).

17. Saboor-Parsa M and Tabatabaee A, Religion, family and sexual behavior in a university population, paper presented at the Second Congress on Family and Sexual Disorders, Tehran, Iran, Nov. 23-24, 2005 (in Persian)

18. Simbar M, Ramezani Tehrani F and Hashemi MS, The reproduc tive health needs of the university students of Qazvin, Journal of Qazvin University of Medical Sciences \& Health Services, 2003, 28:5-13 (in Persian)

19. Mohammad Ket al., Sexual risk-taking behaviors among boys aged 15-18 years in Tehran, Journal of Adolescent Health, 2007, 41(4):407-414.

20. Miller BC, Benson B and Galbraith KA, Family relationships and adolescent pregnancy risk: a research synthesis, Developmental Review, 2001, 21(1):1-38

21. Jaccard J, Dittus PJ and Gordon VV, Maternal correlates of adolescent sexual and contraceptive behavior, Family Planning Perspectives, 1996, 28(4):159-165\& 185

22. Resnick MD et al., Protecting adolescents from harm: findings from the National Longitudinal Study on Adolescent Health, Journal of the American Medical Association, 1997, 278(10):823-832.

23. Weinstein $M$ and Thornton A, Mother-child relations and adolescent sexual attitudes and behavior, Demography, 1989, 26(4):563-577.

24. Danziger SK, Family life and teenage pregnancy in the inner-city: experiences of African-American youth, Children and Youth Services Review, 1995, 17(1-2):183-202.

25. Ku L, Sonenstein FL and Pleck JH, Neighborhood, family and work: influences on the premarital behaviors of adolescent males, Social Forces, 1993, 72(2):479-503.

26. Hogan DP and Kitagawa EM, The impact of social status, family structure, and neighborhood on the fertility of black adolescents, American Journal of Sociology, 1985, 90(4):825-855.

27. Luster T and Small SA, Sexual abuse history and number of sex partners among female adolescents, Family Planning Perspectives, 1997, 29(5):204-211.

28. Luster T and Small SA, Factors associated with sexual risk-taking behaviors among adolescents, Journal of Marriage and the Family, 1994, 56(3):622-632

29. Small SA and Luster T, Adolescent sexual activity: an ecological, risk-factor approach, Journal of Marriage and the Family, 1994, 56(1): 181-192.

30. Gray MR and Steinberg L, Unpacking authoritative parenting: reassessing a multidimensional construct, Journal of Marriage and the Family, 1999, 61(3):574-587.

31. Barber BK, Parental psychological control: revisiting a neglected construct, Child Development, 1996, 67(6):3296-3319.

32. Dorius G and Barber B, Parental support and control and the onset of sexual intercourse, unpublished manuscript, Provo, UT, USA Brigham Young University, 1998.

33. Miller BC et al., Pubertal development, parental communication, and sexual values in relation to adolescent sexual behaviors, Journal of Early Adolescence, 1998, 18(1):27-52.

34. Miller WB et al., Dopamine receptor genes are associated with age 
at first sexual intercourse, Journal of Biosocial Science, 1999, 31(1): 43-54.

35. Feldman SS and Brown NL, Family influences on adolescent male sexuality: the mediational role of self-restraint, Social Development, 1993, 2(1):15-35

36. Benda BB and DiBlasio FA, Comparison of four theories of adolescent sexual exploration, Deviant Behavior, 1991, 12(3):235-257.

37. Whitbeck LB, Conger RD and Kao M-Y, The influence of parental support, depressed affect, and peers on the sexual behaviors of adolescent girls, Journal of Family Issues, 1993, 14(2):261-278.

38. Whitbeck L et al., Parental support, depressed affect, and sexual experience among adolescents, Youth and Society, 1992, 24(2):166177.

39. Laumann EO et al., The Social Organization of Sexuality: Sexual Practices in the United States, Chicago, IL, USA: University of Chicago Press, 1994.

40. Barahini MN, Assessment of reliability and validity of the Eysenck Personality Questionnaire, paper presented at the Seminar on Psychology and Psychiatry, Tehran, Iran, Dec. 20-23, 1993 (in Persian)

41. Jafari F, Poorzarrabi P and Tarokh A, The study of sexual problems among male college students and associated factors, paper presented at the Second Congress on Family and Sexual Disorders, Tehran, Iran, Nov. 23-24, 2005 (in Persian).

42. Mirmolaee ST et al., The study of sexual behaviors and related factors among female students of governmental schools in Tehran, paper presented at the Second Congress on Family and Sexual Disorders, Tehran, Iran, Nov. 23-24, 2005 (in Persian).

43. Kirby D, Antecedents of adolescent initiation of sex, contraceptive use, and pregnancy, American Journal of Health Behavior, 2002, 26(6):473-485.

44. Abraham L and Kumar KA, Sexual experiences and their correlates among college students in Mumbai City, India, International Family Planning Perspectives, 1999, 25(3):139-146 \& 152.

45. Feldman SS and Brown NL, Family influences on adolescent male sexuality: the mediational role of self-restraint, Social Development, 1993, 2(1):15-35.

46. Thornton A and Camburn D, The influence of the family on premarital sexual attitudes and behavior, Demography, 1987, 24(3):323340 .

47. Whitbeck LB, Simons RL and Kao M-Y, The effects of divorced mothers' dating behaviors and sexual attitudes on the sexual attitudes and behaviors of their adolescent children, Journal of Marriage and the Family, 1994, 56(3):615-621

48. Miller BC, Family influences on adolescent sexual and contraceptive behavior, Journal of Sex Research, 2002, 39(1):22-26.

49. Kerr $M$ and Stattin $H$, What parents know, how they know it, and several forms of adolescent adjustment: further support for a reinterpretation of monitoring, Developmental Psychology, 2000, 36(3): 366-380.

50. Alexander $\mathrm{M}$ et al., Correlates of premarital relationships among unmarried youth in Pune district, Maharashtra, India, International Family Planning Perspectives, 2007, 33(4):150-159.

51. Wight D, Williamson L and Henderson M, Parental influences on young people's sexual behaviour: a longitudinal analysis, Journal of Adolescence, 2006, 29(4):473-494.

\section{RESUMEN}

Contexto: Aunque en Irán se desalientan las relaciones premaritales heterosexuales, especialmente las que implican contacto sexual y particularmente para las mujeres, una minoría significativa de personas jóvenes están involucradas en ese tipo de relaciones. Sin embargo, los determinantes de tales relaciones no han sido identificados, especialmente aquellos relativos a la influencia de las familias de las mujeres jóvenes.

Métodos: En el período 2005-2006, una muestra aleatoria de 1,401 mujeres estudiantes universitarias solteras de cuatro universidades en Teherán, completó encuestas anónimas y auto-administradas que preguntaban si las entrevistadas habian tenido alguna vez un novio o si habian tenido relaciones sexuales. Se condujo una serie de análisis de regresión bivariado y multivariado para examinar las asociaciones entre estos resultados y algunos factores familiares, que incluyen medidas socioeconómicas, comunicación entre padres e hijas, y cercanía, valores y atmósfera en la familia, así como control parental.

Resultados: El hecho de haber tenido un novio se asoció positivamente con el ingreso paterno (razón de momios, 1.3), logro educativo de la madre (1.3) y valores familiares más liberales (1.3). Por otro lado, haber tenido un novio se asoció negativamente con la cercanía entre padres e hijas (0.6). Un control de los padres demasiado estricto y demasiado relajado durante la adolescencia se asoció en ambos casos con haber tenido un novio, pero solamente el primero con haber tenido relaciones sexuales premaritales. Adicionalmente, las personas entrevistadas tuvieron mayor probabilidad de haber tenido relaciones sexuales premaritales si no vivían con su padre y su madre (2.0), o si su familia tenía valores más liberales (1.3); por otra parte, tuvieron menores probabilidades de haber tenido relaciones sexuales si tenían una relación estrecha con sus padres (0.7).

Conclusión: Las buenas relaciones familiares pueden reducir la probabilidad de que las mujeres jóvenes se involucren en relaciones sexuales premaritales, posiblemente porque fomentan la cercanía entre padres e hijas. Un control moderado por parte de los padres puede desalentar las relaciones sexuales premaritales de manera más efectiva que el ejercicio de un menor o mayor grado de control.

\section{RÉSUMÉ}

Contexte: Bien que les relations hétérosexuelles antérieures au mariage, impliquant surtout un contact sexuel, soient découragées en Iran, en particulier pour les jeunes femmes, une minorité significative de jeunes s'engagent bel et bien dans de telles relations. Les déterminants de ces relations n'ont cependant pas été identifiés, en ce qui concerne notamment les facteurs familiaux.

Méthodes: En 2005-2006, un échantillon aléatoire de 1.401 étudiantes non mariées prélevé dans quatre universités de Téhéran a été soumis à une enquête anonyme auto-administrée demandant aux participantes si elles avaient jamais eu un petit ami ou des rapports sexuels. Les associations entre ces variables dépendantes et les facteurs familiaux (mesures socioéconomiques, communication et proximité parent-enfant, atmosphère et valeurs familiales et contrôle parental) ont été examinées par analyses bivariées et régressions multivariées.

Résultats: Le fait d'avoir eu un petit ami s'est avéré associé positivement au revenu du père (rapport de probabilités, 1,3), au niveau de scolarité de la mère $(1,3)$ et aux valeurs familiales plus libérales $(1,3)$, et négativement à la proximité parentenfant $(0,6)$. Très strict ou très relâché pendant l'adolescence, 
le contrôle parental est dans les deux cas associé au fait d'avoir eu un petit ami, mais il ne l'est au fait d'avoir eu des rapports sexuels avant le mariage que dans le premier. De plus, les répondantes se sont révélées plus susceptibles d'avoir eu des rapports sexuels avant le mariage si elles ne vivaient pas avec leurs deux parents $(2,0)$ ou si leur famille avait des valeurs plus libérales (1,3). La probabilité s'est révélée moindre pour les filles qui avaient une relation étroite avec leurs parents $(0,7)$.

Conclusion: Les bonnes relations familiales peuvent réduire la probabilité de rapports sexuels antérieurs au mariage chez les jeunes, peut-être en ce qu'elles favorisent la proximité entre les parents et les enfants. Un contrôle parental modéré peut décourager les rapports antérieurs au mariage plus efficacement que les degrés de contrôle moindres ou plus stricts.

\section{Acknowledgments}

The authors are grateful for the dedication and support of Mohammad Ali Mazaheri and Ali Zadeh Mohammadi, who were affiliated with the Family Research Institute when the field work for this study was conducted, and for the assistance of Mohammad Reza Mohammadi, National Research Centre for Medical Science. The authors are grateful to Amir Erfani for his valuable suggestions and for his guidance on the multivariate analysis.

Author contact:faridehfarahani@yahoo.com 